\title{
ANALISA LABORATORIUM SIFAT CAMPURAN POOR GRADED ASPHALT CONCRETE WEARING COURSE (ACWC)
}

\author{
Slamet Budirahardjo ${ }^{{ }^{*}}$, Setyoningsih Wibowo ${ }^{2}$ \\ ${ }^{1}$ Prodi Teknik Sipil FTI . Universitas PGRI Semarang \\ 2Prodi Informatika FTI. Universitas PGRI Semarang \\ Universitas PGRI Semarang JI. Sidodadi Timur No. 24 , Semarang, Jateng, Indonesia \\ *email : meetz.budi@gmail.com
}

\begin{abstract}
The pavement layer arrangement has a function to support and distribute traffic loads with the aim of not causing construction failure or significant damage to the already formed road construction. In connection with the surface course performance which adheres to the principle of long life performance, in order to achieve this, a mixed design plan (Design Mix Formula, DMF) is made in accordance with the road function. The aim of this research is to analyze the value of stability and flexibility to the porosity value of hot asphalt mixture due to poor graded AC-WC mixture of PU Bina Marga 2010 technical specifications which deviates from the optimum mix design plan based on laboratory testing using the Marshall method. Based on the initial target for the gradation of the Laston AC-WC asphalt concrete aggregate mixture according to the technical specifications of Bina Marga in 2010, the Optimum Asphalt Content (KAO) value was obtained at $6.1 \%$. Deviation of the target aggregate mix grading resulted in changes in the properties of the Laston AC-WC hot mix asphalt concrete. The deviation of the properties of the Laston AC-WC asphalt concrete mixture, with $K A O$ conditions $=6.1 \%$, the largest occurred at the target gradient of the type 2 aggregate mixture gap against the initial gradation target of the Laston AC-WC aggregate mixture.
\end{abstract}

Key words: pavement; the Marshall method; optimum bitumen content; hot asphalt mixture.

\begin{abstract}
ABSTRAK
Susunan lapisan perkerasan jalan mempunyai fungsi untuk menopang dan mendistribusikan beban lalu lintas dengan tujuan tidak menimbulkan kegagalan konstruksi atau kerusakan yang berarti terhadap konstruksi jalan yang sudah terbentuk. Berkaitan dengan kinerja lapis permukaan perkerasan jalan (surface course) yang berpegang pada prinsip long life performance, maka guna mewujudkan hal tersebut dibuatlah suatu rancangan campuran rencana (Design Mix Formula, DMF) sesuai dengan fungsi jalan. Tujuan penelitian adalah menganalisa nilai stabilitas dan fleksibilitas terhadap nilai porositas campuran aspal panas akibat poor graded campuran AC-WC spesifikasi teknik PU Bina Marga Tahun 2010 yang menyimpang dari rancangan campuran rencana optimum berdasarkan pengujian di laboratorium dengan menggunakan metode Marshall. Berdasarkan target awal gradasi campuran agregat beton aspal Laston AC-WC sesuai spesikasi teknis Bina Marga Tahun 2010 diperoleh nilai Kadar Aspal Optimum (KAO) sebesar 6,1\%. Penyimpangan target gradasi campuran agregat mengakibatkan perubahan sifat campuran panas beton aspal Laston ACWC. Penyimpangan sifat campuran beton aspal Laston AC-WC kondisi KAO $=6,1 \%$ terbesar terjadi pada target gradasi senjang campuran agregat tipe 2 terhadap target gradasi awal campuran agregat Laston AC-WC.
\end{abstract}

Kata kunci : perkerasan jalan; metode Marshall; kadar aspal optimum; campuran aspal panas.

\section{PENDAHULUAN}

Susunan lapisan perkerasan jalan mempunyai fungsi untuk menopang dan mendistribusikan beban lalu lintas dengan tujuan tidak menimbulkan kegagalan konstruksi atau kerusakan yang berarti terhadap konstruksi jalan yang sudah terbentuk. Lapis permukaan jalan 
khususnya jenis lapis permukaan lentur di Indonesia saat ini yang ada yaitu Laston (Lapisan Aspal Beton) dan Lataston (Lapisan Tipis Aspal Beton), Sukirman, 2003. Lapis permukaan tersebut merupakan elemen dari susunan lapisan perkerasan yang langsung berhadapan dengan beban lalu lintas, sehingga menjadi salah satu elemen sangat penting dari konstruksi jalan.

Berkaitan dengan kinerja lapis permukaan perkerasan jalan (surface course ) yang berpegang pada prinsip long life performance, maka guna mewujudkan hal tersebut dibuatlah suatu rancangan campuran rencana (Design Mix Formula, DMF) sesuai dengan fungsi jalan. Dalam rancangan campuran rencana permukaan perkerasan jalan telah dibuat proporsi bahan penyusun campuran tersebut secara teknis agar didapat campuran yang memenuhi standar persyaratan yang diinginkan. Rancangan campuran rencana perkerasan jalan yang telah disetujui oleh tenaga ahli berkompeten, maka dilakukan uji coba penghamparan dan pemadatan DMF tersebut dilapangan. Selama proses penghamparan DMF dilakukan pengambilan sampel guna diteliti karakteristik fisik dan mekanik dari campuran tersebut. Rancangan campuran rencana yang sesuai dengan proporsi bahan penyusunnya akan menghasilkan lapisan perkerasan yang homogen sebaran butiran bahan penyusunnya.

Ciri dari hasil penghamparan yang sesuai JMF dan prosedur teknis penghamparan adalah sebaran material yang merata. Akan tetapi dalam perjalanan masa konstruksi perkerasan jalan dijumpai adakalanya hasil pemadatan campuran tidak sesuai yang diinginkan, hal ini terlihat dari permukaan perkerasan jalan secara fisik terdapat rongga/celah dalam campuran.

Melihat dari permasalahan yang terjadi, maka tujuan dilakukan penelitian ini adalah menganalisa nilai stabilitas terhadap nilai porositas campuran aspal panas akibat poor graded campuran perkerasan jalan yang menyimpang dari rancangan campuran rencana optimum berdasarkan pengujian di laboratorium. Sedangkan urgensi penelitian menganalisa nilai fleksibilitas terhadap nilai porositas campuran aspal panas akibat poor graded campuran perkerasan jalan yang menyimpang dari rancangan campuran rencana optimum berdasarkan pengujian di laboratorium. Leily Fatmawati, tahun 2013 dengan penelitian yang berjudul "Karakteristik Marshall Dalam Aspal Campuran Panas AC-WC Terhadap Variasi Temperatur Perendaman". Variasi temperatur perendaman yang digunakan adalah $60,65,70,75$ dan 80 derajat celcius. Dari hasil penelitiannya menyatakan bahwa semakin tinggi suhu rendaman, nilai stabilitas Marshall semakin menurun, sedangkan nilai flow naik dengan bertambahnya suhu perendaman, sehingga harga bagi Marshall (MQ) juga turun. Hal ini disebabkan karena suhu yang tinggi melelehkan aspal dalam campuran.

Putri dan Syamsuwirman, variasi subtitusi styrofoam terhadap aspal yang digunakan adalah $0 \%, 1 / 2 \%, 1 \%$ dan $1,5 \%$. Penambahan styrofoam yang optimum yang menghasilkan stabilitas maksimum adalah $1,5 \%$ dengan kadar aspal optimumnya $6,75 \%$. Panungkelan dkk, 2017, semakin banyak jumlah tumbukan nilai stabilitas semakin tinggi, flow semakin rendah, VIM dan VMA semakin kecil dan VFB semakin besar.

\section{METODOLOGI}

Penelitian ini dilakukan di Laboratorium Program Studi Teknik Sipil, Fakultas Teknik Dan Informatika Universitas PGRI Semarang, dengan dasar menggunakan sistem pencampuran aspal panas Laston Wearing Course (AC-WC) mengacu Spesifikasi Teknik Departemen Pekerjaan Umum Bina Marga tahun 2010 yang merupakan dasar dari persyaratan. Di dalam penelitian ini, pengujian dilakukan secara bertahap, yaitu terdiri atas pengujian agregat (kasar, halus dan filler), aspal dan pengujian terhadap campuran (uji Marshall). Pengujian terhadap agregat termasuk pemeriksaan berat jenis dan penyerapan air. Untuk pengujian aspal termasuk juga pengujian penetrasi dan berat jenis. Sedangkan metode yang digunakan sebagai penguji campuran adalah metode Marshall, dimana dari pengujian Marshall tersebut didapatkan hasil-hasil yang berupa properties Marshall yaitu, stabilitas, flow, Void In the Mix (VIM), Void Filled with Asphalt (VFA), Void in Mineral Aggregate (VMA) dan dihitung Marshall Quotient (MQ) nya. 
Kemudian setelah semua pengujian tersebut di atas telah dilalui dan mendapatkan hasil yang berupa data, maka selanjutnya dapat dilakukan perhitungan atau analisa. Dan terakhir, dapat diambil kesimpulan dan juga saran dari penelitian yang telah dilakukan.

Tahapan penelitian atau cara melaksanakan penelitian ini, secara garis besar dapat digambarkan dalam suatu kerangka yang berbentuk diagram alir seperti diagram di bawah ini (Gambar 1)

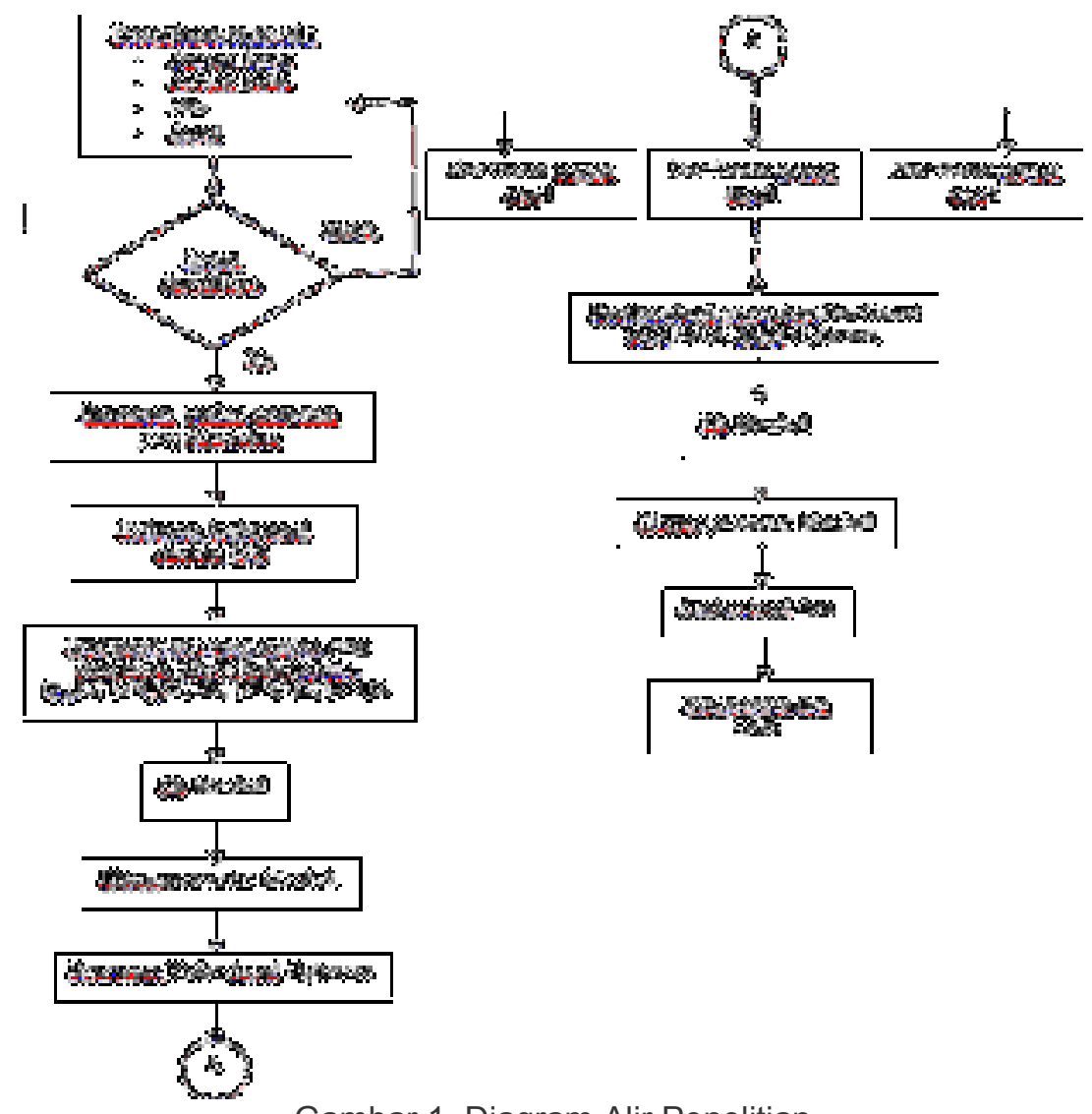

Gambar 1. Diagram Alir Penelitian

Pada penelitian tahap I, beberapa kegiatan yang disiapkan yaitu mempersiapkan material penelitian secara lengkap baik kuantitas maupun kualitas yang meliputi pemilihan jenis agregat yang sesuai dan jenis aspal yang tepat. Selain itu pada tahap ini juga disiapkan semua peralatan penelitian termasuk didalamnya mengadakan kalibrasi peralatan seperti timbangan, alat tumbuk dan peralatan Marshall. Jika semua material/bahan penelitian di atas memenuhi syarat, maka dapat dibuat benda uji sampel dan kemudian diuji dengan Marshall standar, hal ini berguna untuk mendapatkan Kadar Aspal Optimum (KAO) sesuai target rancangan gradasi campuran awal yang diinginkan.

Pada penelitian tahap II ini, setelah Kadar Aspal Optimum ( $\left.K A O=P_{\text {opt }}\right)$ ditentukan sebagai patokan kadar aspal, maka langkah berikutnya adalah membuat benda uji dengan variasi target gradasi selanjutnya yang diinginkan, yaitu poor graded tipe 1, poor graded tipe 2 dan poor graded tipe 3 pada kondisi kadar aspal optimum tersebut.

Dalam penelitian ini, rancangan target campuran benda uji AC-WC ditampilkan seperti pada Gambar 2 sampai 5 dibawah ini. 


\begin{tabular}{|c|c|c|c|c|c|c|c|c|c|c|c|c|c|}
\hline \multirow{2}{*}{ Saringan } & ASTM & $3 / 4 "$ & $1 / 2 "$ & $3 / 8^{\prime \prime}$ & $\# 4$ & $\# 8$ & $\# 16$ & $\# 30$ & $\# 50$ & $\# 100$ & $\# 200$ & Pan & \multirow[t]{7}{*}{ Jumlah } \\
\hline & $(\mathrm{mm})$ & 19 & 12,5 & 9,5 & 4,75 & 2,36 & 1,18 & 0,6 & 0,3 & 0,15 & 0,075 & 0 & \\
\hline \multirow{2}{*}{ Spesifikasi Lolos (\%) } & Max. & 100 & 100 & 90 & 69 & 53 & 40 & 30 & 22 & 15 & 9 & & \\
\hline & Min. & 100 & 90 & 77 & 53 & 33 & 21 & 14 & 9 & 6 & 4 & & \\
\hline \multicolumn{2}{|l|}{ Target Gradasi Agregat Lolos (\%) } & 100 & 95 & 83 & 61 & 43 & 30 & 22 & 15 & 10 & 4 & 0 & \\
\hline \multicolumn{2}{|l|}{ Filler tambahan $(\%)$} & - & - & - & - & - & - & - & - & - & 2 & - & \\
\hline \multicolumn{2}{|l|}{ Total Target Gradasi Lolos (\%) } & 100 & 95 & 83 & 61 & 43 & 30 & 22 & 15 & 10 & 6 & 0 & \\
\hline \multicolumn{2}{|l|}{ Kebutuhan agregat (gram) } & 0 & 55 & 132 & 242 & 198 & 143 & 88 & 77 & 55 & 66 & 44 & 1100 \\
\hline \multicolumn{2}{|l|}{ Kebutuhan filler tambahan (gram) } & & & & & & & & & & & 22 & \\
\hline
\end{tabular}

Gambar 2. Rancangan Target Campuran Laston AC-W (Awal)

\begin{tabular}{|c|c|c|c|c|c|c|c|c|c|c|c|c|c|}
\hline \multirow{2}{*}{ Saringan } & ASTM & $3 / 4 "$ & $1 / 2 "$ & $3 / 8^{\prime \prime}$ & \#4 & $\# 8$ & $\# 16$ & $\# 30$ & $\# 50$ & $\# 100$ & $\# 200$ & Pan & \multirow[t]{7}{*}{ Jumlah } \\
\hline & $(\mathrm{mm})$ & 19 & 12,5 & 9,5 & 4,75 & 2,36 & 1,18 & 0,6 & 0,3 & 0,15 & 0,075 & 0 & \\
\hline \multirow{2}{*}{ Spesifikasi Lolos (\%) } & Max. & 100 & 100 & 90 & 69 & 53 & 40 & 30 & 22 & 15 & 9 & & \\
\hline & Min. & 100 & 90 & 77 & 53 & 33 & 21 & 14 & 9 & 6 & 4 & & \\
\hline \multicolumn{2}{|l|}{ Target Gradasi Agregat Lolos (\%) } & 100 & 93 & 79 & 55 & 33 & 32 & 30 & 15 & 10 & 4 & 0 & \\
\hline \multicolumn{2}{|l|}{ Filler tambahan $(\%)$} & - & - & - & - & - & - & - & - & - & 2 & - & \\
\hline \multicolumn{2}{|l|}{ Total Target Gradasi Lolos (\%) } & 100 & 93 & 79 & 55 & 33 & 32 & 30 & 15 & 10 & 6 & 0 & \\
\hline \multicolumn{2}{|l|}{ Kebutuhan agregat (gram) } & 0 & 77 & 154 & 264 & 242 & 11 & 22 & 165 & 55 & 66 & 44 & 1100 \\
\hline \multicolumn{2}{|l|}{ Kebutuhan filler tambahan (gram) } & & & & & & & & & & & 22 & \\
\hline
\end{tabular}

Gambar 3. Rancangan Target Campuran Laston AC-WC (Tipe 1)

\begin{tabular}{|c|c|c|c|c|c|c|c|c|c|c|c|c|c|}
\hline \multirow{2}{*}{ Saringan } & ASTM & $3 / 4 "$ & $1 / 2 "$ & $3 / 8^{\prime \prime}$ & $\# 4$ & $\# 8$ & $\# 16$ & $\# 30$ & $\# 50$ & $\# 100$ & $\# 200$ & Pan & \multirow[t]{7}{*}{ Jumlah } \\
\hline & $(\mathrm{mm})$ & 19 & 12,5 & 9,5 & 4,75 & 2,36 & 1,18 & 0,6 & 0,3 & 0,15 & 0,075 & 0 & \\
\hline \multirow{2}{*}{ Spesifikasi Lolos (\%) } & Max. & 100 & 100 & 90 & 69 & 53 & 40 & 30 & 22 & 15 & 9 & & \\
\hline & Min. & 100 & 90 & 77 & 53 & 33 & 21 & 14 & 9 & 6 & 4 & & \\
\hline \multicolumn{2}{|l|}{ Target Gradasi Agregat Lolos (\%) } & 100 & 98 & 88 & 67 & 33 & 23 & 22 & 20 & 13 & 5 & 0 & \\
\hline \multicolumn{2}{|l|}{ Filler tambahan $(\%)$} & - & - & - & - & - & - & - & - & - & 2 & - & \\
\hline \multicolumn{2}{|l|}{ Total Target Gradasi Lolos (\%) } & 100 & 98 & 88 & 67 & 33 & 23 & 22 & 20 & 13 & 7 & 0 & \\
\hline \multicolumn{2}{|l|}{ Kebutuhan agregat (gram) } & 0 & 22 & 110 & 231 & 374 & 110 & 11 & 22 & 77 & 88 & 55 & 1100 \\
\hline \multicolumn{2}{|l|}{ Kebutuhan filler tambahan (gram) } & & & & & & & & & & & 22 & \\
\hline
\end{tabular}

Gambar 4. Rancangan Target Campuran Laston AC-WC Tipe 2)

\begin{tabular}{|c|c|c|c|c|c|c|c|c|c|c|c|c|c|}
\hline \multirow{2}{*}{ Saringan } & ASTM & $3 / 4^{\prime \prime}$ & $1 / 2 "$ & $3 / 8 "$ & $\# 4$ & \# 8 & $\# 16$ & $\# 30$ & $\# 50$ & \#100 & $\# 200$ & Pan & \multirow[t]{7}{*}{ Jumlah } \\
\hline & $(\mathrm{mm})$ & 19 & 12,5 & 9,5 & 4,75 & 2,36 & 1,18 & 0,6 & 0,3 & 0,15 & 0,075 & 0 & \\
\hline \multirow{2}{*}{ Spesifikasi Lolos (\%) } & Max. & 100 & 100 & 90 & 69 & 53 & 40 & 30 & 22 & 15 & 9 & & \\
\hline & Min. & 100 & 90 & 77 & 53 & 33 & 21 & 14 & 9 & 6 & 4 & & \\
\hline \multicolumn{2}{|l|}{ Target Gradasi Agregat Lolos (\%) } & 100 & 95 & 83 & 61 & 43 & 27 & 24 & 21 & 8 & 3 & 0 & \\
\hline \multicolumn{2}{|l|}{ Filler tambahan $(\%)$} & - & - & - & - & - & - & - & - & - & 2 & - & \\
\hline \multicolumn{2}{|l|}{ Total Target Gradasi Lolos (\%) } & 100 & 95 & 83 & 61 & 43 & 27 & 24 & 21 & 8 & 5 & 0 & \\
\hline \multicolumn{2}{|l|}{ Kebutuhan agregat (gram) } & 0 & 55 & 132 & 242 & 198 & 176 & 33 & 33 & 143 & 55 & 33 & 1100 \\
\hline \multicolumn{2}{|l|}{ Kebutuhan filler tambahan (gram) } & & & & & & & & & & & 22 & \\
\hline
\end{tabular}

Gambar 5. Rancangan Target Campuran Laston AC-WC (Tipe 3)

\section{HASIL DAN PEMBAHASAN}

Pelaksanaan pemeriksaan material dalam penelitian ini berdasarkan standar rujukan pengujian Standar Nasional Indonesia (SNI). Adapun pemeriksaan material penyusun campuran AC-WC dalam penelitian ini meliputi pemeriksaan sifat aspal, sifat agregat kasar dan agregat halus serta sifat material pengisi atau filler semen.

Hasil pemeriksaan material aspal Pen. 60/70 Ex. Pertamina dapat dilihat pada Tabel 1 di bawah ini.

Tabel 1. Hasil Pemeriksaan Aspal Pen. 60/70

\begin{tabular}{ccccccc}
\hline No. & Item Pemeriksaan & Satuan & \multicolumn{2}{c}{ Spesifikasi } & Hasil & Standar Rujukan \\
\cline { 4 - 4 } & & & Min. & Max. & & \\
\hline 1 & Penetrasi aspal & $0,1 \mathrm{~mm}$ & 60 & 70 & 63 & SNI 06-2456- \\
& & & & & & 1991 \\
2 & Berat jenis aspal & - & 1 & - & 1,037 & SNI 2441-2011 \\
\hline
\end{tabular}

Adapun hasil dari pemeriksaan agregat kasar dan agregat halus dapat dilihat pada Tabel 62 di bawah ini.

Tabel 2. Hasil Pemeriksaan Agregat Kasar dan Agregat Halus Agregat batu pecah maks. $3 / 4 "$ 


\begin{tabular}{clcc}
\hline No. & \multicolumn{1}{c}{ Pemeriksaan } & Standar pengujian & Hasil \\
\hline 1 & Berat jenis bulk & SNI 1969:2008 & 2,619 \\
2 & Berat jenis apparent & SNI 1969:2008 & 2,762 \\
3 & Penyerapan & SNI 1969:2008 & $1,98 \%$ \\
4 & Kelekatan terhadap agregat & SNI 03-2439-1991 & $98 \%$ \\
Agregat batu pecah maks. 1/2” & & \\
No. Pemeriksaan & & Standar pengujian & Hasil \\
1 & Berat jenis bulk & SNI 1969:2008 & 2,626 \\
2 & Berat jenis apparent & SNI 1969:2008 & 2,781 \\
\hline 3 & Penyerapan & SNI 1969:2008 & $2,12 \%$ \\
4 & Kelekatan terhadap agregat & SNI 03-2439-1991 & $98 \%$ \\
Agregat abu batu & & \\
No. & & Standar pengujian & Hasil \\
\hline 1 & Berat jenis bulk & SNI 1970:2008 & 2,565 \\
\hline 2 & Berat jenis apparent & SNI 1970:2008 & 2,719 \\
3 & Penyerapan & SNI 1970:2008 & $2,21 \%$ \\
\hline
\end{tabular}

Untuk hasil pemeriksaan material filler dalam pembuatan campuran AC-WC dapat dilihat pada Tabel 3 dibawah ini.

Tabel 3. Hasil Pemeriksaan Material Filler

\begin{tabular}{llll}
\hline No. & Pemeriksaan & Standar pengujian & Hasil \\
\hline 1 & Berat jenis bulk filler abu batu & SNI 3423:2008 & 2,539 \\
2 & Berat jenis bulk filler semen & SNI 3423:2008 & 3,08 \\
\hline
\end{tabular}

Perhitungan penentuan nilai $\mathrm{Pb}$ optimum ini berdasarkan persamaan sebagai berikut :

$$
\mathrm{Pb}=0,035(\mathrm{CA})+0,045(\mathrm{FA})+0,18(\mathrm{FF})+\mathrm{K}
$$

Dimana :

$\mathrm{CA}=$ persentase agregat kasar, dari target awal agregat campuran $=57$

$\mathrm{FA} \quad=$ persentase agregat halus, dari target awal agregat campuran $=37$

$\mathrm{FF} \quad=$ persentase agregat filler, dari target awal agregat campuran $=6$

$\mathrm{K}=$ konstanta untuk campuran Laston $(0,5-1,0)$, diambil $=1,0$

Adapun hasil pengujian campuran panas beton aspal AC-WC padat guna menentukan nilai Kadar Aspal Optimum (KAO) dengan metode Marshall dapat dilihat pada Gambar 6 dibawah ini.

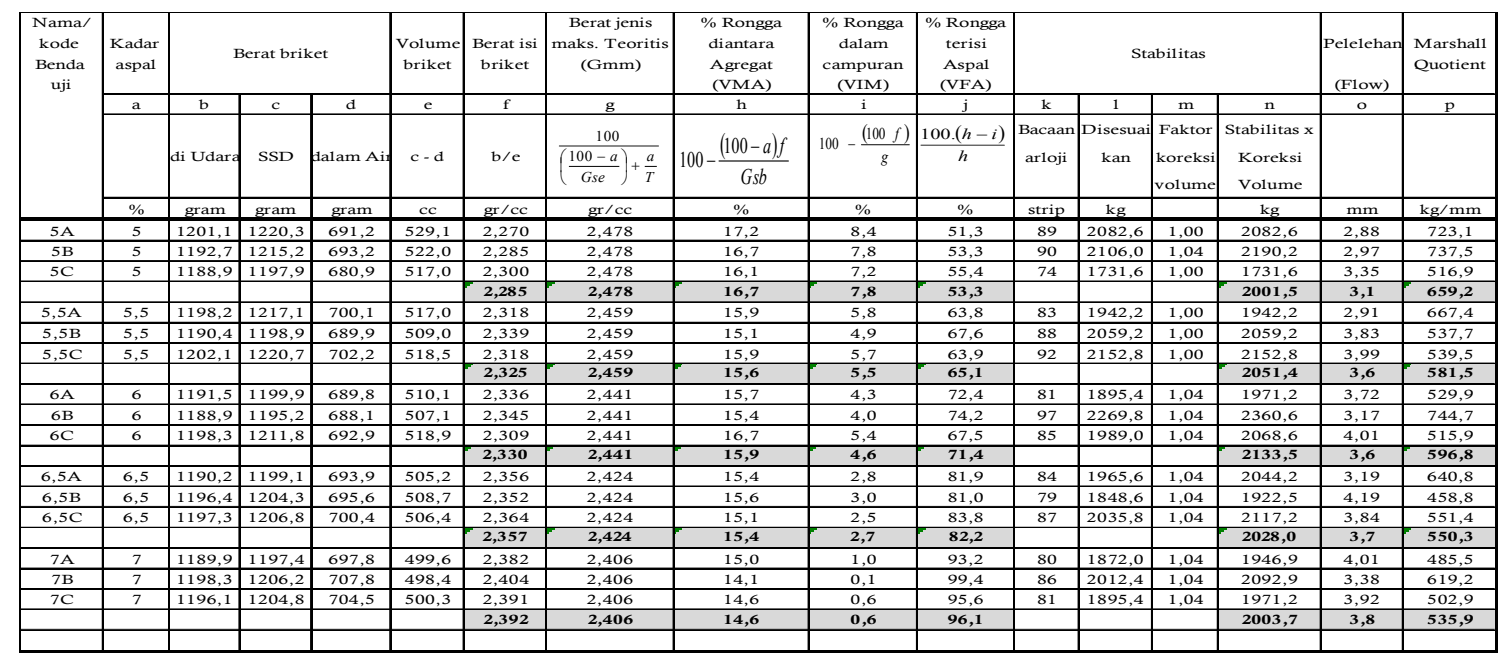

Gambar 6. Hasil Pengujian Campuran Panas Beton Aspal AC-WC Padat dengan metode Marshall 
Berdasarkan analisa karakteristik campuran AC-WC sesuai hasil data Gambar 6 di atas maka ditentukan nilai KAO sebesar 6,1\%, sedangkan hasil pemeriksaan uji Marshall target awal gradasi campuran AC-WC kondisi KAO (tipe 1,23) dapat dilihat pada Gambar 7,8,9.

\begin{tabular}{|c|c|c|c|c|c|c|c|c|c|c|c|c|c|c|c|c|}
\hline \multirow{4}{*}{$\begin{array}{l}\text { Nama/ } \\
\text { kode } \\
\text { Benda } \\
\text { uji }\end{array}$} & $\begin{array}{c}\text { Kadar } \\
\text { aspal }\end{array}$ & \multicolumn{3}{|c|}{ Berat briket } & \multirow{2}{*}{\begin{tabular}{|c}
$\begin{array}{c}\text { Volume } \\
\text { briket }\end{array}$ \\
$\mathrm{e}$ \\
\end{tabular}} & \multirow{2}{*}{\begin{tabular}{|c}
$\begin{array}{c}\text { Berat isi } \\
\text { briket }\end{array}$ \\
$\mathrm{f}$ \\
\end{tabular}} & \multirow{2}{*}{$\begin{array}{c}\begin{array}{c}\text { Berat jenis } \\
\text { maks. Teoritis } \\
\text { (Gmm) }\end{array} \\
\mathrm{g} \\
\end{array}$} & \multirow{2}{*}{$\begin{array}{c}\text { \% Rongga } \\
\text { diantara } \\
\text { Agregat } \\
\text { (VMA) } \\
\mathrm{h} \\
\end{array}$} & \multirow{2}{*}{$\begin{array}{c}\begin{array}{c}\text { \%ongga } \\
\text { dalam } \\
\text { campuran } \\
\text { (VIM) }\end{array} \\
\mathrm{i} \\
\end{array}$} & \multirow{2}{*}{\begin{tabular}{|c|}
$\begin{array}{c}\text { \% Rongga } \\
\text { terisi } \\
\text { Aspal } \\
\text { (VFA) }\end{array}$ \\
$\mathrm{j}$ \\
\end{tabular}} & \multicolumn{4}{|c|}{ Stabilitas } & \multirow{2}{*}{ 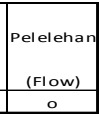 } & \multirow{2}{*}{$\begin{array}{c}\begin{array}{c}\text { Marshall } \\
\text { Quotient }\end{array} \\
\mathrm{p} \\
\end{array}$} \\
\hline & $a$ & $\mathrm{~b}$ & $\mathrm{c}$ & $d$ & & & & & & & $\mathrm{k}$ & $\mathrm{I}$ & $\mathrm{m}$ & $n$ & & \\
\hline & & di Udara & SSD & dalam Air & $c-d$ & $\mathrm{~b} / \mathrm{e}$ & $\frac{100}{\left(\frac{100-a}{\text { Gse }}\right)+\frac{a}{T}}$ & $100-\frac{(100-a) f}{G s b}$ & $100-\frac{(100 f)}{g}$ & $\frac{100 .(h-i)}{h}$ & $\begin{array}{c}\text { Bacaan } \\
\text { arloji }\end{array}$ & $\begin{array}{c}\text { Disesua } \\
\text { kan }\end{array}$ & \begin{tabular}{|c|c|} 
Faktor \\
koreksi \\
volume
\end{tabular} & $\begin{array}{c}\text { Stabilitas } x \\
\text { Koreksi } \\
\text { Volume }\end{array}$ & & \\
\hline & $\%$ & gram & gram & gram & $\mathrm{cc}$ & $\mathrm{gr} / \mathrm{cc}$ & $\mathrm{gr} / \mathrm{cc}$ & $\%$ & $\%$ & $\%$ & strip & $\mathrm{kg}$ & & $\mathrm{kg}$ & $\mathrm{mm}$ & $\mathrm{kg} / \mathrm{mm}$ \\
\hline 5,6-1.A & 5,6 & 1189,4 & 1199,1 & 692,5 & 506,6 & 2,348 & 2,460 & 15,1 & 4,6 & 69,8 & 91 & 2129,4 & 1,04 & 2214,6 & 2,77 & 799,5 \\
\hline 5,6-1.B & 5,6 & 1190,5 & 1201,3 & 693,3 & 508,0 & 2,344 & 2,460 & 15,2 & 4,7 & 68,9 & 83 & 1942,2 & 1,04 & 2019,9 & 2,52 & 801,5 \\
\hline \multirow[t]{2}{*}{ 5,6-1.C } & 5,6 & 1188,9 & 1199,1 & 698,3 & 500,8 & 2,374 & 2,460 & 14,1 & 3,5 & 75,3 & 81 & 1895,4 & 1,04 & 1971,2 & 3,08 & 640,0 \\
\hline & & & & & & 2,355 & 2,460 & 14,8 & 4,3 & 71,3 & & & & 2068,6 & 2,8 & 747,0 \\
\hline 6,1-1.A & 6,1 & 1197,2 & 1208,5 & 696,7 & 511,8 & 2,339 & 2,442 & 15,8 & 4,2 & 73,4 & 84 & 1965,6 & 1,00 & 1965,6 & 3,17 & 620,1 \\
\hline $6,1-1 . B$ & 6,1 & 1179,7 & 1190,1 & 692,9 & 497,2 & 2,373 & 2,442 & 14,6 & 2,8 & 80,6 & 88 & 2059,2 & 1,04 & 2141,6 & 2,99 & 716,2 \\
\hline \multirow[t]{2}{*}{ 6,1-1.C } & 6,1 & 1192,1 & 1200,9 & 691,9 & 509,0 & 2,342 & 2,442 & 15,7 & 4,1 & 74,0 & 79 & 1848,6 & 1,00 & 1848,6 & 4,02 & 459,9 \\
\hline & & & & & & 2,351 & 2,442 & 15,4 & 3,7 & 76,0 & & & & 1985,3 & 3,4 & 598,7 \\
\hline $6,6-1 . A$ & 6,6 & 1199,5 & 1208,7 & 700,1 & 508,6 & 2,358 & 2,424 & 15,6 & 2,7 & 82,6 & 69 & 1614,6 & 1,00 & 1614,6 & 4,41 & 366,1 \\
\hline $6,6-1 . B$ & 6,6 & 1188,7 & \begin{tabular}{|l|}
1198,2 \\
\end{tabular} & 700,4 & 497,8 & 2,388 & 2,424 & 14,5 & 1,5 & 89,7 & 74 & \begin{tabular}{|l|}
1731,6 \\
\end{tabular} & 1,04 & 1800,9 & 3,99 & 451,3 \\
\hline \multirow[t]{3}{*}{ 6,6-1.C } & 6,6 & \begin{tabular}{|l|}
1198,2 \\
\end{tabular} & \begin{tabular}{|l|}
1206,9 \\
\end{tabular} & 701,7 & 505,2 & 2,372 & 2,424 & 15,1 & 2,2 & 85,7 & 71 & 1661,4 & 1,04 & 1727,9 & 4,21 & 410,4 \\
\hline & & & & & & 2,373 & 2,424 & 15,1 & 2,1 & 86,0 & & & & 1714,4 & 4,2 & 409,3 \\
\hline & & & & & & & & & & & & & & & & \\
\hline
\end{tabular}

Gambar 7. Hasil Pemeriksaan Uji Marshall Target Awal Gradasi Campuran AC-WC Kondisi KAO (Tipe 1)

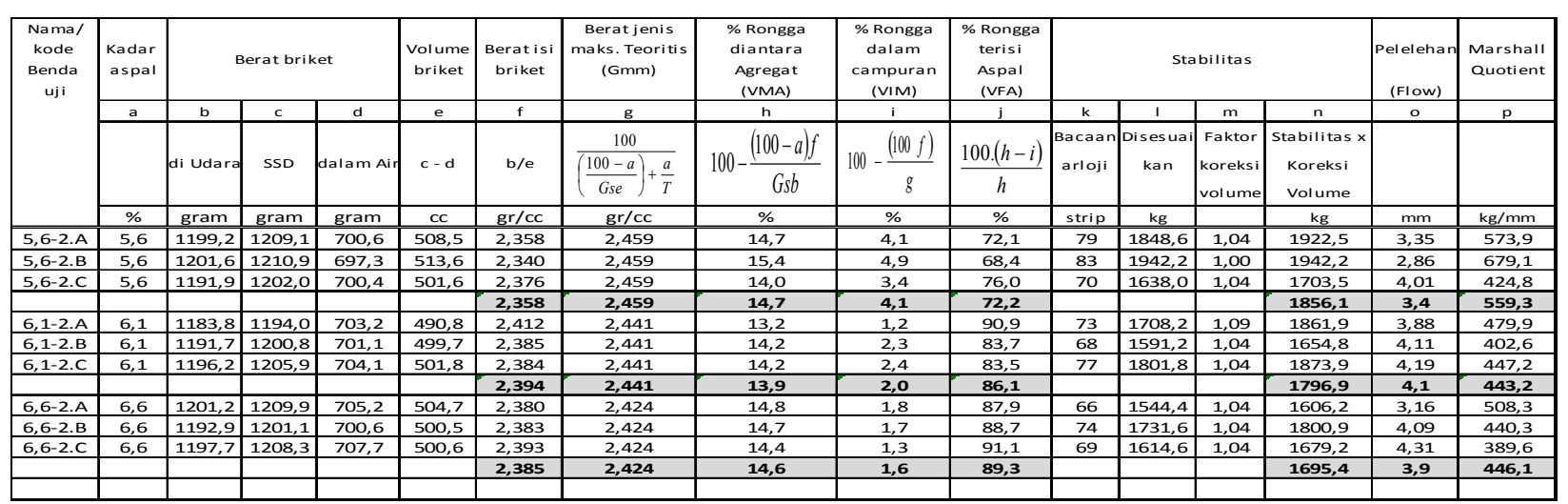

Gambar 8. Hasil Pemeriksaan Uji Marshall Target Awal Gradasi Campuran AC-WC Kondisi KAO (Tipe 2)

\begin{tabular}{|c|c|c|c|c|c|c|c|c|c|c|c|c|c|c|c|c|}
\hline \multirow{5}{*}{$\begin{array}{c}\text { Nama/ } \\
\text { kode } \\
\text { Benda } \\
\text { uji }\end{array}$} & $\begin{array}{c}\text { Kadar } \\
\text { aspal }\end{array}$ & \multicolumn{3}{|c|}{ Berat briket } & \multirow{2}{*}{$\begin{array}{c}\begin{array}{c}\text { Volume } \\
\text { briket }\end{array} \\
\mathrm{e} \\
\end{array}$} & \multirow{2}{*}{$\begin{array}{c}\begin{array}{c}\text { Berat isi } \\
\text { briket }\end{array} \\
f \\
\end{array}$} & \multirow{2}{*}{$\begin{array}{c}\begin{array}{c}\text { Berat jenis } \\
\text { maks. Teoritis } \\
\text { (Gmm) }\end{array} \\
\mathrm{g} \\
\end{array}$} & \multirow{2}{*}{$\begin{array}{c}\begin{array}{c}\text { \% Rongga } \\
\text { diantara } \\
\text { Agregat } \\
\text { (VMA) }\end{array} \\
\mathrm{h} \\
\end{array}$} & \multirow{2}{*}{$\begin{array}{c}\text { \% Rongga } \\
\text { dalam } \\
\text { campuran } \\
\text { (VIM) } \\
\text { i } \\
\end{array}$} & \multirow{2}{*}{$\begin{array}{c}\text { \% Rongga } \\
\text { terisi } \\
\text { Aspal } \\
\text { (VFA) } \\
\mathrm{j} \\
\end{array}$} & \multicolumn{4}{|c|}{ Stabilitas } & \multirow{2}{*}{$\begin{array}{c}\text { Pelelehan } \\
\text { (Flow) } \\
0 \\
\end{array}$} & \multirow{2}{*}{$\begin{array}{c}\text { Marshall } \\
\text { Quotient } \\
p \\
p\end{array}$} \\
\hline & $a$ & $\mathrm{~b}$ & $\mathrm{c}$ & $d$ & & & & & & & $\mathrm{k}$ & 1 & $\mathrm{~m}$ & $n$ & & \\
\hline & & & & & & & 100 & $(100-a) f$ & $(100 f)$ & $100(h-i)$ & Bacaan & Disesuai & Faktor & Stabilitas $x$ & & \\
\hline & & di Udara & SSD & dalam Air & $c-d$ & $\mathrm{~b} / \mathrm{e}$ & $\left(\frac{100-a}{\text { Gse }}\right)+\frac{a}{T}$ & $100-\frac{(100 \text { usJ }}{\text { Gsb }}$ & $100-$ & $\underline{100 .(n-i)}$ & arloji & kan & $\begin{array}{l}\text { koreksi } \\
\text { volume }\end{array}$ & $\begin{array}{l}\text { Koreksi } \\
\text { Volume }\end{array}$ & & \\
\hline & $\%$ & gram & gram & gram & $\mathrm{cc}$ & $\mathrm{gr} / \mathrm{cc}$ & $\mathrm{gr} / \mathrm{cc}$ & $\%$ & $\%$ & $\%$ & strip & $\mathrm{kg}$ & & $\mathrm{kg}$ & $\mathrm{mm}$ & $\mathrm{kg} / \mathrm{mm}$ \\
\hline $5,6-3 . A$ & 5,6 & 1186,9 & \begin{tabular}{|l|}
1197,2 \\
\end{tabular} & 680,8 & 516,4 & 2,298 & 2,457 & 16,7 & 6,4 & 61,4 & 74 & 1731,6 & 1,00 & 1731,6 & 2,11 & 820,7 \\
\hline $5,6-3 . B$ & 5,6 & 1190,5 & \begin{tabular}{|l|}
1199,1 \\
\end{tabular} & 688,2 & 510,9 & 2,330 & 2,457 & 15,5 & 5,1 & 66,9 & 81 & \begin{tabular}{|l|}
1895,4 \\
\end{tabular} & 1,04 & 1971,2 & 3,71 & 531,3 \\
\hline \multirow[t]{2}{*}{$5,6-3 . C$} & 5,6 & 1197,4 & 1208,0 & 693,2 & 514,8 & 2,326 & 2,457 & 15,7 & 5,3 & 66,1 & 88 & 2059,2 & 1,00 & 2059,2 & 2,55 & 807,5 \\
\hline & & & & & & 2,318 & 2,457 & 16,0 & 5,6 & 64,8 & & & & 1920,7 & 2,8 & 719,8 \\
\hline 6,1-3.A & 6,1 & 1200,7 & 1209,9 & 700,3 & 509,6 & 2,356 & 2,439 & 15,1 & 3,4 & 77,5 & 83 & 1942,2 & 1,00 & 1942,2 & 3,99 & 486,8 \\
\hline $6,1-3 . B$ & 6,1 & 1193,8 & 1202,1 & 690,9 & 511,2 & 2,335 & 2,439 & 15,8 & 4,2 & 73,2 & 89 & 2082,6 & 1,00 & 2082,6 & 4,18 & 498,2 \\
\hline \multirow{2}{*}{$6,1-3 . C$} & 6,1 & 1197,4 & 1206,6 & 693,8 & 512,8 & 2,335 & 2,439 & 15,8 & 4,3 & 73,1 & 78 & 1825,2 & 1,00 & 1825,2 & 4,47 & 408,3 \\
\hline & & & & & & 2,342 & 2,439 & 15,6 & 4,0 & 74,6 & & & & 1950,0 & 4,2 & 464,4 \\
\hline 6,6-3.A & 6,6 & 1199,9 & 1208,9 & 702,1 & 506,8 & 2,368 & 2,421 & 15,1 & 2,2 & 85,4 & 77 & 1801,8 & 1,04 & 1873,9 & 3,87 & 484,2 \\
\hline $6,6-3 . B$ & 6,6 & 1201,1 & 1210,5 & 700,7 & 509,8 & 2,356 & 2,421 & 15,5 & 2,7 & 82,7 & 81 & 1895,4 & 1,00 & 1895,4 & 4,82 & 393,2 \\
\hline \multirow{3}{*}{$6,6-3 . C$} & 6,6 & 1193,8 & 1202,8 & 700,1 & 502,7 & 2,375 & 2,421 & 14,8 & 1,9 & 87,1 & 73 & 1708,2 & 1,04 & 1776,5 & 4,39 & 404,7 \\
\hline & & & & & & 2,366 & 2,421 & 15,2 & 2,3 & 85,1 & & & & 1848,6 & 4,4 & 427,4 \\
\hline & & & & & & & & & & & & & & & & \\
\hline
\end{tabular}

Gambar 9. Hasil Pemeriksaan Uji Marshall Target Awal Gradasi Campuran AC-WC Kondisi KAO (Tipe 3)

Penyimpangan sifat campuran beton aspal Laston AC-WC kondisi $\mathrm{KAO}=6,1 \%$ terbesar terjadi pada target gradasi senjang campuran agregat tipe 2 terhadap target gradasi awal campuran 
agregat Laston AC-WC sebagai berikut: nilai VIM turun dari nilai 3,91\% menjadi 1,95\%, nilai VFA naik dari nilai 74,87\% menjadi 86,05\%, nilai stabilitas turun dari nilai 2309,19 kg menjadi 1796,89 $\mathrm{kg}$ dan nilai $\mathrm{MQ}$ turun dari nilai $705,39 \mathrm{~kg} / \mathrm{mm}$ menjadi $443,25 \mathrm{~kg} / \mathrm{mm}$. Sedangkan penyimpangan target gradasi campuran agregat Laston AC-WC yang terjadi pada gradasi campuran agregat tipe 2 dibandingkan dengan target awal gradasi campuran laston AC-WC sebagai berikut: lolos saringan $1 / 2 "=+3 \%$, lolos saringan $3 / 8 "=5 \%$, lolos saringan \#4 = $6 \%$, lolos saringan \#8 = $-10 \%$, lolos saringan \#16 = -7\%, lolos saringan \#50 = $+5 \%$, lolos saringan $\# 100=+3 \%$ dan lolos saringan $\# 200=+1 \%$.

\section{KESIMPULAN}

Dari hasil analisa perhitungan dan pembahasan pelaksanaan pengujian diatas, maka dapat dambil kesimpulan sebagai berikut:

a. Berdasarkan target awal gradasi campuran agregat beton aspal Laston AC-WC sesuai spesikasi teknis Bina Marga Tahun 2010, maka pada pengujian campuran aspal panas Laston AC-WC diperoleh nilai Kadar Aspal Optimum (KAO) sebesar 6,1\%.

b. Penyimpangan sifat campuran beton aspal Laston AC-WC kondisi $\mathrm{KAO}=6,1 \%$ terbesar terjadi pada target gradasi senjang campuran agregat tipe 2 terhadap target gradasi awal campuran agregat Laston AC-WC sebagai berikut: nilai VIM turun dari nilai 3,91\% menjadi $1,95 \%$, nilai VFA naik dari nilai $74,87 \%$ menjadi $86,05 \%$, nilai stabilitas turun dari nilai 2309,19 $\mathrm{kg}$ menjadi $1796,89 \mathrm{~kg}$ dan nilai $\mathrm{MQ}$ turun dari nilai $705,39 \mathrm{~kg} / \mathrm{mm}$ menjadi $443,25 \mathrm{~kg} / \mathrm{mm}$.

c. Penyimpangan target gradasi campuran agregat Laston AC-WC yang terjadi pada gradasi campuran agregat tipe 2 dibandingkan dengan target awal gradasi campuran laston AC-WC sebagai berikut: lolos saringan $1 / 2 "=+3 \%$, lolos saringan $3 / 8 "=5 \%$, lolos saringan $\# 4=6 \%$, lolos saringan \#8 = $-10 \%$, lolos saringan \#16 = -7\%, lolos saringan \#50 $=+5 \%$, lolos saringan $\# 100=+3 \%$ dan lolos saringan $\# 200=+1 \%$.

\section{DAFTAR PUSTAKA}

Putri, E.E dan Syamsuwirman. (2016). Tinjauan Subtitusi Styrofoam Pada Aspal Pen. 60/70 Terhadap Kinerja Campuran Asphalt Concrete-Wearing Course (AC-WC), Jurnal Teknik Sipil Universitas Syah Kuala, Volume 6, Nomor 1, September 2016.

Panungkelan, K.S dkk. (2017). Pengaruh Jumlah Tumbukan Pemadatan Benda Uji Terhadap Besaran Marshall Campuran Beraspal Panas Bergradasi Menerus Jenis Asphalt Concrete (AC), Jurnal Sipil Statik Vol.5 No.8, Oktober 2017.

Kementerian Pekerjaan Umum Dan Perumahan Rakyat, Direktorat Jenderal Bina Marga. (2010). Spesifikasi Umum 2010 (Revisi 3).

Fatmawati, L. (2013) Karakteristik Marshall Dalam Aspal Campuran Panas AC-WC Terhadap Variasi Temperatur Perendaman, Jurnal Wahana TEKNIK SIPIL Vol.18 No.2, Desember 2013.

Koestalam, P \& Sutoyo. (2010) Perancangan Tebal Perkerasan Jenis Lentur (Flexible Pavement) dan Jenis Kaku (Rigit Pavement) (Sesuai AASHTO 1986)), Yayasan Badan Penerbit Pekerjaan Umum PT. Mediatama Saptakarya, Cetakan pertama.

Bitumen, S. (1990). The Shell Bitumen Hand Book, Published By Shell Bitumen, East Molesey Serrey.

Sukirman, S. ( 2003). Beton Aspal Campuran Panas, Granit Jakarta 2003.

The Asphalt Institute. (1993). Mix Design Methods for Asphalt Concrete and other Hot Mix Types, Manual Series No.2 (MS-2), Sixth Edition, Lexington, Kentucky, USA, Asphalt Institute.

Yoder dan Witczak. (1975). Principles of Pavement Design, $2^{\text {nd }}$ Edition, John Wiley \& Sons, Inc. 